\title{
Analisis Pengaruh Pertumbuhan Ekonomi dan Upah Minimum terhadap Penyerapan Tenaga Kerja di Kabupaten Malang
}

\author{
Ririn Rusniati, Sudarti, Atut Frida Agustin \\ Program Studi Ekonomi Syari'ah, \\ Fakultas Agama Islam, Universitas Muhammadiyah Malang \\ Email: Ririnrusniati39@gmail.com
}

\begin{abstract}
The purpose of this study is to determine the effect of economic growth and minimum wage on labor absorption at Malang Regency in 2002-2016. The method of analysis used in this research is multiple linear regression. The results showed that economic growth had a positive and significant effect on labor absorption in Malang Regency in 2002-2016 with t value (3.54)> t table $(1,79588)$ and significant value 0,0041 (below 5\%). Based on the results of these studies can be taken information that the higher economic growth hence the absorption of labor will increase. Minimum wage has negative and insignificant effect on labor absorption in Malang Regency in 2002-2016 with $\mathrm{t}$ value $(-0.42)<\mathrm{t}$ table $(1,79588)$ and significant value 0,6792 (above $5 \%$ ). Based on the results of this study can be taken information that the higher minimum wage will lead to reduced absorption of labor in Malang regency. Economic growth and minimum wages have a significant effect simultaneously on the absorption of manpower in Malang district in 2002-2016. This is indicated by the value of $\mathrm{F}$ arithmetic (6.44)> F table (3.59) with significant value of 0.012553 .
\end{abstract}

Keywords: Economic Growth, Minimum Wages, Labor Absorption. 


\begin{abstract}
ABSTRAK
Penelitian ini bertujuan untuk mengetahui pengaruh pertumbuhan ekonomi dan upah minimum terhadap penyerapan tenaga kerja di Kabupaten Malang pada tahun 2002 hingga tahun 2016. Penelitian ini bejenis kuantitatif, dengan menggunakan analisis regresi linear berganda. Hasil penelitian menunjukkan bahwa pertumbuhan ekonomi berpengaruh positif dan signifikan terhadap penyerapan tenaga kerja di Kabupaten Malang tahun 2002-2016 dengan nilai t hitung $(3,54)>\mathrm{t}$ tabel (1,79588) dan nilai signifikan sebesar 0,0041 (dibawah 5\%). Berdasarkan hasil penelitian tersebut dapat diambil infomasi bahwa semakin tinggi pertumbuhan ekonomi maka penyerapan tenaga kerja akan meningkat. Upah minimum berpengaruh negatif dan tidak signifikan terhadap penyerapan tenaga kerja di Kabupaten Malang tahun 2002-2016 dengan nilai t hitung $(-0,42)<\mathrm{t}$ tabel $(1,79588)$ dan nilai signifikan sebesar 0,6792 (diatas 5\%). Berdasarkan hasil penelitian dapat disimpulkan bahwa semakin tinggi upah minimum akan menyebabkan berkurangnya penyerapan tenaga kerja di Kabupaten Malang. Pertumbuhan ekonomi dan upah minimum berpengaruh signifikan secara simultan terhadap penyerapan tenaga kerja di Kabupaten Malang tahun 2002-2016 dengan nilai $\mathrm{F}$ hitung $(6,44)>\mathrm{F}$ tabel $(3,59)$ dengan nilai signifikan sebesar 0,012553 .
\end{abstract}

Kata Kunci: Pertumbuhan Ekonomi, Upah Minimum, Penyerapan Tenaga Kerja.

\title{
1. Pendahuluan
}

Sumber daya manusia merupakan salah satu faktor yang paling penting dalam perkembangan ekonomi jangka panjang, dimana potensi suatu negara untuk memperoleh tingkat pertumbuhan ekonomi sebagian besar dipengaruhi oleh sumber daya manusia. Sebagaimana yang dikatakan oleh Profesor Frederick Harbison bahwa bukanlah sumber daya modal atau materi yang sepenuhnya menentukan karakterisasi dan tingkat perkembangan ekonomi dan sosial, melainkan sumber daya manusia. Sumber daya manusia merupakan landasan utama bagi kesejahteraan setiap negara. Sumber daya modal dan alam merupakan faktor produksi yang pasif, sedangkan manusia merupakan faktor produksi yang aktif yang dapat mengakumulasi modal, mengolah sumber daya alam, serta melaksanakan pembangunan nasional lebih lanjut (Todaro, 2001: 385).

Tenaga kerja merupakan kendaraan yang akan mendorong pembangunan ekonomi karena tenaga kerja adalah faktor yang sangat penting dalam proses produksi. Berbagai penelitian mengenai sumber-sumber pertumbuhan ekonomi di negara-negara barat menghasilkan bahwa sumber utama yang menyebabkan kemajuan ekonomi di negara-negara maju bukanlah pertumbuhan modal fisik 
melainkan petumbuhan modal manusia (Todaro, 2001: 385). Menurut Herianingrum (2016: 228) begitu pentingnya peranan sumber daya manusia sehingga suatu wilayah dengan kekayaan alam yang melimpah tidak akan mampu memenuhi permintaan masyarakat setempat apabila di wilayah tersebut minim tenaga kerja yang mampu menggali dan mengolah alam tersebut dengan baik. Sebaliknya apabila pada suatu wilayah yang minim sumber daya modal, akan tetapi memiliki banyak tenaga kerja dengan skill yang tinggi, maka sumber daya alam yang sedikit tadi dapat diolah secara maksimal sehingga dapat memenuhi kebutuhan masyarakat di wilayah tersebut.

Disamping sebagai faktor utama dan faktor penting bagi pembangunan ekonomi suatu negara, di sisi lain tenaga kerja bisa menimbulkan berbagai masalah, antara lain jumlah pengangguran yang tinggi, jumlah angkatan kerja yang semakin meningkat, mutu tenaga kerja yang rendah, kemiskinan dan lain sebagainya. Apabila masalah tersebut terjadi pada suatu negara maka proses pembangunan yang ada di negara tersebut akan terhambat. Oleh karena itu perlu adanya peran pemerintah untuk mengatasi masalah-masalah tersebut (Fitriasari, 2016). Semakin banyak jumlah tenaga kerja yang tersedia maka akan meningkatkan pengangguran apabila hal tersebut tidak di imbangi dengan kesempatan kerja sehingga akan meningkatkan kemiskinan, kriminalitas, dan fenomena-fenomena sosial-ekonomi di masyarakat.

Adapun penggunaan tenaga kerja dalam Islam berorientasi pada penggunaan tenaga kerja yang lebih banyak, penuh keberkahan dan tidak berorientasi pada duniawi atau keuntungan semata (Herianingrum, 2016: 225). Islam telah menjelaskan bahwa dengan bekerja maka seseorang akan mendapatkan apa yang diinginkannya. Sebagaimana firman Allah SWT dalam QS. An-Najm [53] : 39. Salah satu faktor yang dapat meningkatkan kesempatan kerja adalah pertumbuhan ekonomi. Pertumbuhan ekonomi berkaitan erat dengan tingkat produksi. Karena pertumbuhan ekonomi mencerminkan kenaikan output maka semakin banyak barang atau jasa yang diproduksi akan diikuti oleh pertumbuhan ekonomi yang semakin tinggi. Akan tetapi kompleksitas masalah tenaga kerja tidak hanya pada kuantitas tenaga kerja yang mampu diserap oleh perekonomian, namun masalah sesungguhnya adalah bagaimana kemampuan perekonomian dalam menyediakan kesempatan kerja berkulaitas yang mampu memberikan harapan dan optimisme kehidupan bagi tenaga kerja yang terserap dan bekerja di sektor tersebut (Malik, 2013: 14).

Pertumbuhan ekonomi yang mencerminkan kesejahteraan masyarakat harus tercermin pada berkurangnya tingkat kemiskinan yang ada di daerah tersebut. Karena hal tersebut membuktikan bahwa suatu daerah telah mencapai tingkat penggunaan tenaga kerja penuh yang tercermin dari berkurangnya tingkat kemiskinan sebagaimana yang dikemukakan oleh Sukirno bahwa Suatu negara dianggap sudah mencapai tingkat penggunaan tenaga kerja penuh/kesempatan kerja penuh apabila dalam perekonomian suatu negara tingkat kemiskinannya kurang dari 4 persen (Sukirno, 2011: 19). Angka kemiskinan di Kabupaten 
Malang masih terbilang tinggi, dimana pada tahun 2012-2017 persentasenya masih bertahan di angka 11. Hal ini dapat dilihat pada tabel persentase kemiskinan dan penduduk miskin di Kabupaten Malang pada tahun 2012-2017 berikut,

Gambar 1.1

Penduduk Kemiskinan di Kabupaten Malang Tahun 2012 - 2017

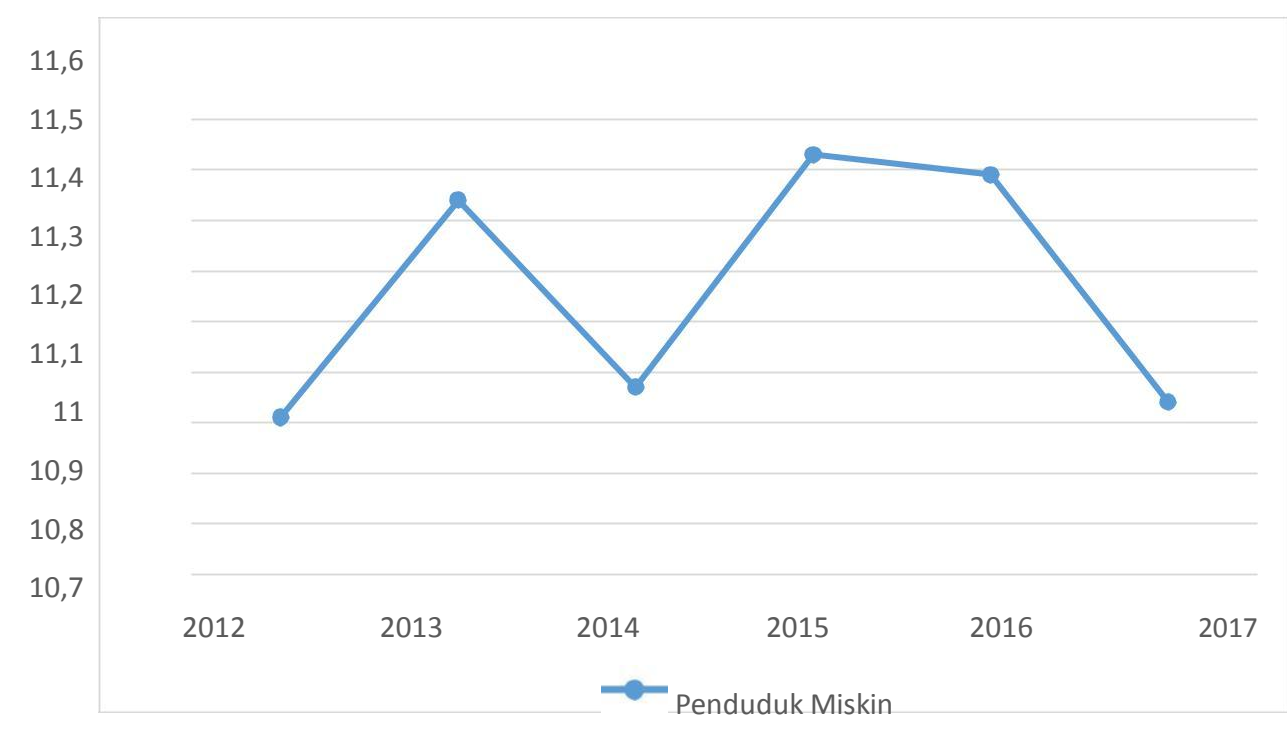

Sumber: BPS Kabupaten Malang

Berdasarkan grafik diatas dapat diketahui bahwa garis kemiskinan di Kabupaten Malang masih bertahan di angka 11 dan 12 persen. Menurut Gatot Suharmoko (Kasi Neraca Wilayah Analisis Statistik BPS Kabupaten Malang), ada beberapa faktor yang menyebabkan angka kemiskinan di Kabupaten Malang tetap bertahan di dua digit atau diatas $10 \%$. Diantaranya, melemahnya pertumbuhan ekonomi dunia yang jelas berdampak kepada masyarakat, ditambah terus menurunnya daya beli masyarakat dan minimnya lapangan pekerjaan (detiknews, 27/2/2018).

Untuk menjamin kesejahteraan dan melindungi para pekerja agar keuntungan tidak hanya dinikmati pengusaha saja, maka pemerintah menetapkan upah minimum yang harus dibayarkan pengusaha kepada buruh sehingga dapat tercipta pemerataan distribusi pendapatan. Upah minimum Kota/Kabupaten adalah besaran upah minimum yang diterima pekerja tetap di sektor formal di suatu kota/kabupaten berdasarkan kriteria hidup layak (KHL) yang diajukan tiap 
tahunnya (BI, 2012: 104). Penentuan upah minimum ditentukan secara terpusat oleh Departement Tenaga Kerja untuk wilayah di seluruh Indonesia. Adapun besarnya upah minimum ditentukan berdasarkan faktor-faktor seperti: kemampuan perusahaan, tingkat pengupahan di sektor atau sub sektor yang sama pada wilayah atau provinsi lain, kondisi perekonomian, dan standar kebutuhan kehidupan pekerja dan keluarga (Aprilia, 2016).

\section{Kajian Pustaka}

\subsection{Pertumbuhan Ekonomi}

Menurut Sukirno (2011: 29), pertumbuhan ekonomi ialah perkembangan kegiatan ekonomi yang berlaku dari waktu ke waktu dan menyebabkan pendapatan nasional riil semakin bekembang. Tingkat pertumbuhan ekonomi menunjukkan persentasi kenaikan pendapatan nasional riil pada suatu tahun tertentu apabila dibandingkan dengan pendapatan nasional riil pada tahun sebelumnya. Pertumbuhan ekonomi bukan hanya aktivitas produksi saja, lebih dari itu pertumbuhan ekonomi merupakan aktivitas menyeluruh dalam bidang produksi yang berkaitan erat dengan keadilan distribusi. Pertumbuhan bukan hanya persoalan ekonomi, melainkan aktivitas manusia yang ditujukan untuk kemajuan sisi materiel dan spritual manusia (Huda, 2015: 124).

Beberapa pemahaman pokok mengenai pertumbuhan ekonomi yang dilihat dari perspektif Islam diantaranya mengenai batasan tentang persoalan ekonomi. Perspektif Islam tidaklah sama dengan yang dianut oleh kapitalis, dimana yang dimaksud dengan persoalan ekonomi yaitu persoalan kekayaan dan minimnya sumber-sumber kekayaan. Perspektif Islam menyatakan bahwa hal itu sesuai dengan kapasitas yang telah disediakan oleh Allah untuk memenuhi kebutuhan manusia yang ditujukan untuk mengatasi persoalan kehidupan manusia (Huda, 2015: 125).

\subsection{Upah Minimum}

Upah minimum sebagaimana yang telah diatur dalam PP No. 8/1981 merupakan upah yang ditetapkan secara Minimum Regional, Sektoral Regional maupun Subsektoral. Dalam hal ini upah minimum itu adalah upah pokok dan tunjangan (Sumarsono, 2003: 156). Peraturan Menteri juga menetapkan upah minimum sektoral pada tingkat provinsi harus lebih tinggi sedikitnya lima persen dari standar upah minimum yang ditetapkan untuk tingkat provinsi. Demikian juga, upah minimum sektoral di tingkat kabupaten atau kota harus lebih tinggi lima persen dari standar upah minimum kabupaten atau kota.

Islam mengakui bahwa dengan manusia bekerja disertai dengan penggunaan modal akan didapat output yang lebih tinggi. Pada umumnya pekerja 
sering mendapat perlakuan kurang adil dari majikannya, padahal hasil kerja dari para pekerja tersebut telah menghasilkan keuntungan yang tidak sedikit, akan tetapi pengusaha sering melupakan kewajibannya terhadap pekerja. Menurut Herianingrum (2016: 230) Permasalahan yang bisa muncul pada pekerja adalah terkait upah dan jenis pekerjaannya. Rasulullah selalu menganjurkan kepada para sahabat agar membayar upah buruhnya dengan upah yang pantas. Sahabat Anas ra., telah meriwayatkan bahwa rasulullah tidak pernah memberikan upah yang rendah pada siapapun. Rasulullah SAW. juga memerintahkan, "Hendaknya upah buruh dibayarkan sebelum keringat mereka kering” (HR. Ibn Majah dan Baihaqi).

\subsection{Penyerapan Tenaga Kerja}

Penyerapan tenaga kerja adalah diterimanya para pelaku tenaga kerja untuk melakukan tugas sebagaimana mestinya, atau adanya suatu keadaan yang menggambarkan tersedianya pekerjaan (lapangan pekerjaan) untuk diisi oleh para pencari kerja (Tohar, 2000: 10). Salah satu faktor produksi yang sangat penting dalam proses produksi adalah tenaga kerja. Tenaga kerja merupakan input yang tidak saja memiliki komponen fisik namun juga mempunyai daya pikir, dan perasaan. Amat pentingnya kedudukan faktor produksi tenaga kerja sehingga suatu proses produksi tidak dapat berjalan tanpa adanya unsur manusia baik secara langsung maupun tidak langsung.

Islam mendorong umatnya untuk bekerja dan memproduksi, bahkan menjadikannya sebagai sebuah kewajiban terhadap orang-orang yang mampu. Allah akan memberi balasan yang setimpal bagi orang yang mau bekerja dan berusaha. Sebagaimana firman Allah dalam QS. an-Nahl [16]: 97.

\section{Metode Penelitian}

Penelitian ini merupakan jenis penelitian deskriptif kuantitatif. Data yang dipakai pada penelitian ini adalah data PDRB Atas Dasar Harga Konstan (ADHK) yang dihitung tahunan dan dinyatakan dalam satuan persen (\%) per tahun, upah minimum Kabupaten. Malang, dan penduduk usia 15 tahun keatas yang bekerja menurut lapangan usaha di Kabupaten Malang. Jenis data yang digunakan dalam penelitian ini adalah data kuantitatif. Jenis data yang digunakan dalam penelitian ini adalah data kuantitatif. Sumber data dalam penelitian ini berasal dari data sekunder. Data sekunder adalah data yang diperoleh dari sumber-sumber tidak langsung. Dalam penelitian ini data sekunder diperoleh dari BPS Kabupaten Malang. Data yang digunakan adalah data time series periode dari tahun 2002 sampai dengan 2016. 


\section{Hasil dan Pembahasan}

\subsection{Pengaruh Pertumbuhan Ekonomi Terhadap Penyerapan Tenaga} Kerja

Dari hasil penelitian di Kabupaten Malang tahun 2002-2016 menunjukkan bahwa variabel pertumbuhan ekonomi berpengaruh positif dan signifikan terhadap penyerapan tenaga kerja dimana diperoleh nilai t hitung $(3.54)>t$ tabel $(1,79588)$ dan nilai signifikan sebesar 0,0041 (dibawah 5\%). Berdasarkan hasil penelitian tersebut dapat diambil informasi bahwa jika pertumbuhan ekonomi meningkat maka penyerapan tenaga kerja akan meningkat.

Tabel 4.1: Hasil Uji t

\begin{tabular}{|l|c|c|c|c|}
\hline Variabel & Koefisien & t-Statistik & t-Tabel & Signifikan \\
\hline $\mathrm{C}$ & 5,944428 & 21,84750 & 1,79588 & 0,0000 \\
\hline $\mathrm{PE}$ & 0,032022 & 3,250814 & 1,79588 & 0,0069 \\
\hline $\mathrm{UM}$ & $-0,003208$ & $-0,065998$ & 1,79588 & 0,9485 \\
\hline
\end{tabular}

Sumber: Data diolah, 2018

Hasil penelitian ini sesuai dengan penelitian yang dilakukan oleh Azaini (2014) bahwa pertumbuhan ekonomi berpengaruh positif dan signifikan terhadap penyerapan tenaga kerja.

\subsection{Pengaruh Upah Minimum Terhadap Penyerapan Tenaga Kerja}

Berdasarkan hasil penelitian di Kabupaten Malang tahun 2002-2016 menunjukkan bahwa variabel upah minimum tidak berpengaruh signifikan dan bertanda negatif terhadap penyerapan tenaga kerja dimana diperoleh nilai t hitung $(-0.42)<\mathrm{t}$ tabel $(1,79588)$ dan nilai signifikan sebesar 0,6792 (diatas 5\%). Berdasarkan hasil penelitian tersebut dapat diambil informasi bahwa semakin tinggi upah minimum akan menyebabkan berkurangnya/rendahnya tingkat penyerapan tenaga kerja di Kabupaten Malang.

Upah minimum tidak berpengaruh signifikan terhadap penyerapan tenaga kerja di kabupaten Malang karena mayoritas masyarakat di kabupaten Malang bekerja pada sektor informal dimana pada sektor tersebut tidak ditetapkan upah minimum akan tetapi upah yang diberikan tergantung dari kontribusi dan hasil yang diperoleh untuk setiap hari maupun setiap bulannya. Hasil penelitian ini sesuai dengan penelitian yang dilakukan oleh Buchari (2016) bahwa upah minimum tidak berpengaruh signifikan terhadap penyerapan tenaga kerja. 


\subsection{Pengaruh Pertumbuhan Ekonomi dan Upah Minimum Terhadap} Penyerapan Tenaga Kerja

Berdasarkan hasil pengujian yang telah dilakukan menunjukkan bahwa pertumbuhan ekonomi dan upah minimum secara bersama-sama berpengaruh signifikan terhadap penyerapan tenaga kerja di Kabupaten Malang tahun 20022016.

\section{Gambar 4.2.: Hasil Uji F}

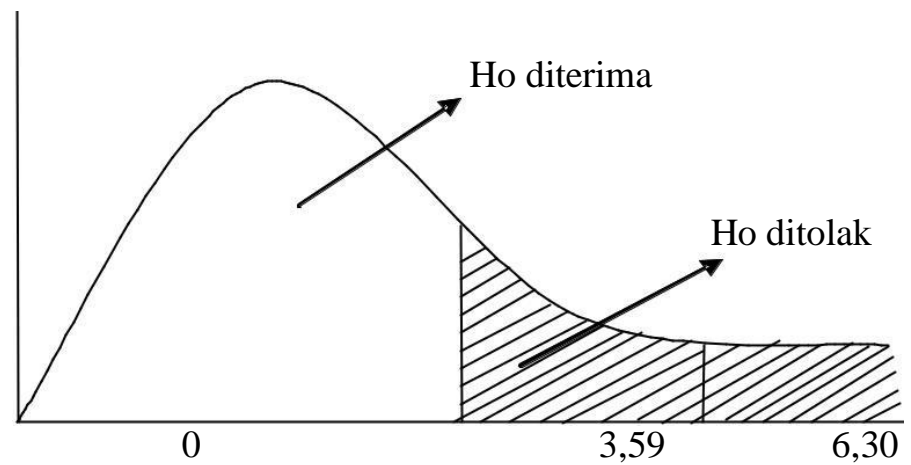

Sumber: Data diolah, 2018

Berdasarkan perhitungan melalui eviews 6 , diperoleh nilai $\mathrm{F}$ hitung sebesar 6.44 dengan nilai signifikan sebesar 0.012553 Nilai df1 sebesar 3, dan df2 $=\mathrm{n}-\mathrm{k}-1=15-3-1=11$ pada $\alpha=5 \%(0,05)$ dan nilai $\mathrm{F}$ tabel sebesar 3.59. Dengan demikian, nilai F-hitung > F-tabel (6.44 > 3.59). Maka Ho ditolak dan Ha diterima, artinya pertumbuhan ekonomi dan upah minimum secara bersama-sama berpengaruh signifikan terhadap penyerapan tenaga kerja di Kabupaten Malang tahun 2002-2016. Hal ini sejalan dengan penelitian yang dilakukan oleh Fitriasari (2016) bahwa pertumbuhan ekonomi dan upah minimum sedara bersama-sama berpengaruh signifikan terhadap penyerapan tenaga kerja.

\section{Kesimpulan}

Berdasarkan hasil analisis data dan pembahasan mengenai Analisis Pengaruh Pertumbuhan Ekonomi Dan Upah Minimum Terhadap Penyerapan Tenaga Kerja Di Kabupaten Malang pada tahun 2002-2016, maka dapat disimpulkan beberapa hal berikut; pertama, pertumbuhan ekonomi memiliki pengaruh positif dan signifikan terhadap penyerapan tenaga kerja di Kabupaten Malang pada tahun 2002-2016. Hal ini ditunjukkan oleh nilai t hitung (3.54) > t tabel $(1,79588)$ dan nilai signifikan sebesar 0,0041 (dibawah 5\%). 
Kedua, upah minimum memiliki pengaruh negatif dan tidak signifikan terhadap penyerapan tenaga kerja di Kabupaten Malang pada tahun 2002-2016. Hal ini ditunjukkan oleh nilai $t$ hitung $(-0.42)<\mathrm{t}$ tabel $(1,79588)$ dan nilai signifikan sebesar 0,6792 (diatas 5\%). Ketiga, pertumbuhan ekonomi dan upah minimum memiliki pengaruh positif dan signifikan secara bersama-sama terhadap penyerapan tenaga kerja di kabupaten Malang pada tahun 2002-2016. Hal ini ditunjukkan oleh nilai F hitung (6.44) > F tabel (3.59) dengan nilai signifikan sebesar 0.012553. Keempat, upah minimum tidak berpengaruh signifikan terhadap penyerapan tenaga kerja di Kabupaten Malang tahun 2002-2016 disebabkan oleh mayoritas masyarakat di kabupaten Malang bekerja pada sektor informal.

\section{Daftar Pustaka}

Aprilia, et, all. 2016. Analisis Ketimpangan Penyerapan Tenaga Kerja Sektor Industri Pengolahan Di Kabupaten/Kota Jawa Timur. Jurnal Ekonomi Pembangunan. Vol 14 No. 02. Desember 2016.

Fitriasari, Dwi. 2016. Pengaruh Pertumbuhan Ekonomi Dan Upah Minimum Terhadap Penyerapan Tenaga Kerja (Studi Kasus Pada Tahun 2011-2014 Di Kabupaten Pati). Skripsi Sekolah Tinggi Agama Islam Negeri (STAIN) Kudus.

FORDEBI, ADESY. 2016. Ekonomi Dan Bisnis Islam. Jakarta: PT Raja Grafindo Persada.

http://detik.id/6HSZo9 diakses pada tanggal 27 Februari 2018

Huda, Nurul. 2015. Ekonomi Pembangunan Islam. Jakarta: Pranamedia Group. Kajian Ekonomi Regional Provinsi Jawa Timur Triwulan IV-2012. Bank Indonesia.

Malik, Nazarudin. 2013. Dinamika Pasar Tenaga Kerja Indonesia. Malang: UMM Press.

Sukirno, Sadono. 2011. Makroekonomi: Teori Pengantar, Jakarta: PT.Rajagrafindo Persada Sumarsono, Sonny. (2003).Ekonomi Manajemen Sumberdaya Manusia dan Ketenagakerjaan. Yogyakrta: Graha Ilmu.

Syamil Qur'an. Bukhara: Al-Qur'an Tajwid \& Terjemahan. Jakarta.

Todaro, Michael P. 2001. Ekonomi Untuk Negara Berkembang. Bumi Aksara: Jakarta.

Tohar, M. 2000. Membuka Usaha Kecil. KANISIUS: Yogyakarta 